\title{
ECONOMIC IMPACTS OF THE COVID-19 PANDEMIC ON THE HOTEL BUSINESS IN ZIMBABWE
}

\author{
Felicity N Ncube ${ }^{1}$, Oliver Chikuta ${ }^{2}$, Vitalis Basera ${ }^{3^{\star}}$, Rudorwashe Baipai ${ }^{4}$, Precious \\ Mazhande $^{5}$, Musawenkosi M. Tapfuma ${ }^{6}$ \\ ${ }^{1,5,6}$ Department of Tourism and Hospitality Management, Midlands State University, \\ Gweru, Zimbabwe \\ ${ }^{2}$ Faculty of Hospitality and Sustainable Tourism, BOTHO University, \\ Gaborone, Botswana \\ ${ }^{3,4}$ Department of Tourism and Hospitality Management, Manicaland State \\ University of Applied Sciences (MSUAS), Mutare, Zimbabwe \\ *Corresponding author's email: vitalisbasera@yahoo.com
}

\begin{abstract}
It is evident from literature that the spread of the Covid-19 pandemic has brought the world economies to its 'knees'. No industry has gone untouched by the effects of this pandemic. Globally there has been an adverse impact on travel which is backbone of the hotel industry. This study focuses on exploring the impact that the Covid-19 pandemic has had on Zimbabwean hotel sector. The objectives of the study focused on investigating the impact of Covid-19 pandemic on hotel occupancy and revenue and proposing strategies that can be implemented for recovery post the pandemic. The study adopted a mixed method approach, semi-structured questionnaires were used to gather data from 29 (3-5 star) hotel management across the various major tourism cities in Zimbabwe. Findings reveal that the Covid19 pandemic has had an adverse impact on hotel occupancy and revenue. Occupancy and revenue have dropped. Strategies have been employed by hotel to cope with the adverse impact of reduced occupancy and revenue, these include working with minimal staff to avoid increases exposure, closing other parts of the hotel to reduce operational cost and operating on take out bases. It can be concluded that hotels in Zimbabwe are not prepared for pandemics like Covid-19. It is therefore recommended that disaster management plans relating to pandemics be developed and implemented by hotels.
\end{abstract}

Keywords: Covid-19; Economic impact; Hotel industry, Occupancy, Pandemic 


\section{INTRODUCTION}

During the last quarter of the year 2019, the China city of Wuhan experienced an outbreak of the novel corona virus which was later named Covid 19. By March 2020, the virus had spread to the tourism regions of the Americas and Europe. Africa was one of the last regions to be affected by the virus (WHO 2020). The global pandemic has brought the entire socio-economic structures of countries to a standstill while challenging global operations of business (Ranasinghe et al, 2020). The Corona virus outbreak resulted in many governments imposing restrictions on travel to other regions especially those affected by the virus (Ozili \& Arun, 2020). This has seen an indefinite suspension of tourism travel (Ozili \& Arun, 2020) which makes up the bulk of the hotel business. Airports and the transport sector have shut down somewhat hindering any form of travel. The 'stay at home' and 'social distancing' policies have restricted even domestic movement, and this has led to rapid shutdown of many cities and resorts which in turn has thrown many hotels into a sudden shock. This study therefore sought to explore the economic impact of the pandemic on the hotel sector in Zimbabwe through determining its impact on hotel occupancies and revenues.

\section{Background of Covid -19 Pandemic}

The novel coronavirus (Covid 2019) first case was reported in Wuhan, capital city of Hubei province, China in December 2019 (Bakar \& Rosbi, 2020). The highly contagious disease had affected about 41 people in Wuhan by January 2020 and it rapidly spread across the Wuhan region forcing the government of China to impose a lockdown of the region in an effort to contain the disease (Santos del Valle, 2020; Gössling et al., 2020). The lockdown imposed on Wuhan by the Chinese government meant that travel in and out of the Wuhan region was banned and individuals were required to adhere to certain quarantine measures (Hoque et al., 2020). According to the World Health Organisation (WHO) as quoted by Gössling et al (2020); Folinas \& Metaxas (2020) and Bakar \& Rosbi (2020), the number of Covid 19 cases continued to increase in mainland China and by February 2020, about 80000 positive cases were reported. By beginning of March 2020, coronavirus positive cases across 
the globe had surpasses 1, 400, 000. By mid-March the virus had spread to about 146 countries across the globe (Bakar \& Rosbi, 2020). Initially, the virus was disregarded by some countries despite warning by the WHO that the virus had potential to spread exponentially. Global air transport facilitated the spread of the virus to other countries(Gössling et al., 2020).

While the spread of the virus was initially aided by international travel, it was latter through local transmissions (Hoque et al., 2020). The World Health Organisation declared the virus a pandemic on 11 March 2020 (AU report, 2020; Bakar \& Rosbi, 2020; Wang \& Wang, 2020). By mid-April the infections had accelerated to about 2 million confirmed cases and over 125000 deaths in 200 countries worldwide. To date the Global numbers, stand at 31867173 positive cases, 21999987 and 976258 deaths (WHO Situation report, 24 September 2020, 10:00 CET). The rapid spreading of the virus prompted governments to adopt the lockdown approach which resulted in closure of boarders, travel restrictions, quarantines and social distancing. All these measures impacted negatively on travel and tourism (Bakar \& Rosbi, 2020).

\section{International Tourism Before the Pandemic}

International tourism has been booming since the 1950s and since then, the sector has contributed significantly to the global economy. In 1950 international tourists' arrivals were recorded at 25 million and have been on the increase, with 450 million arrivals being recorded in 1990. UNWTO estimated the number of international tourism arrivals at 1.4 billion by 2018 , accounting for $\$ 1.4$ trillion and a contribution of $7 \%$ to goods and services worldwide (Folinas \& Metaxas, 2020). In 2019 tourism contributed 10.4\% to GDP globally (Santos del Valle, 2020; International Labour Organization, 2020). UNWTO had forecasted an increase in international tourist arrivals by 1.6 billion in 2020 . 


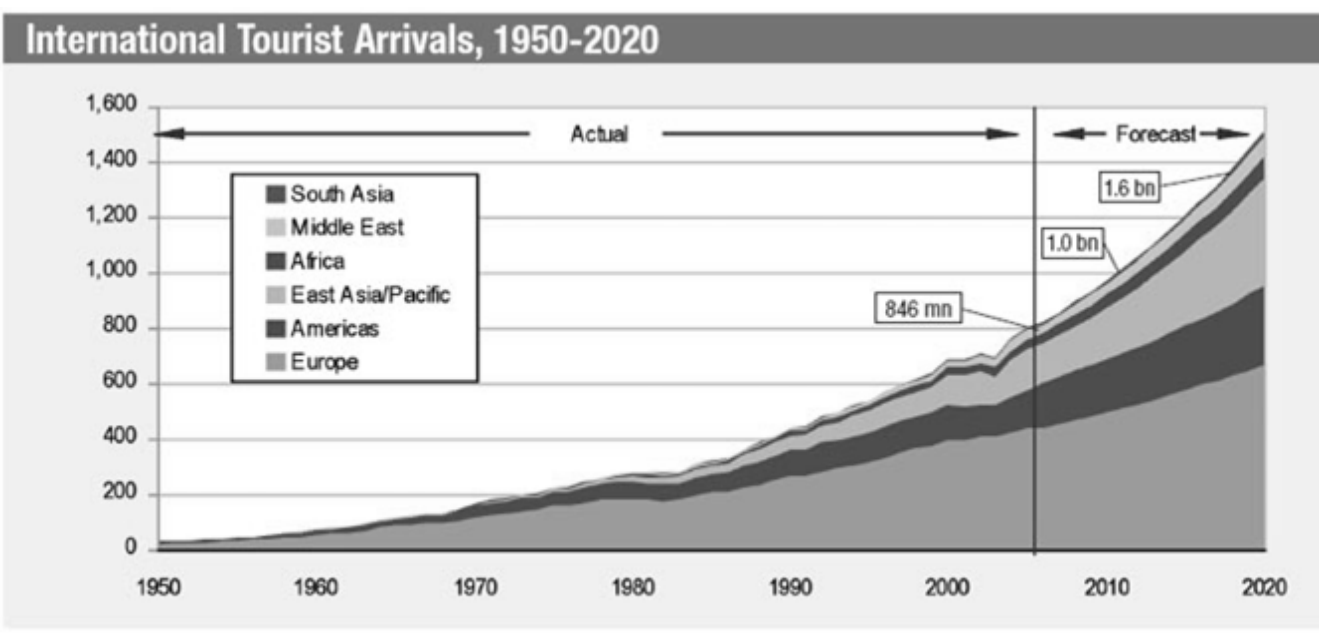

Source: World Tourism Organization (UNWTO) $\odot$

Figure 1. UNWTO International Tourist Arrivals (Actual Trend and Forecast 1950-2020)

This phenomenal growth in international tourism has been attributed to a number of factors that have prevailed in global economy over the past decades. Globalisation fuelled up by invention of new technologies brought the world into one village thereby promoting international travel (Folinas \& Metaxas, 2020). Development of low-cost airlines and fast jets made international travel cheaper and faster. Increase in disposable incomes and change in lifestyles of masses due to increased affluence globally contributed to the increase in international tourism over the past years. Emergence of the affluent middle class in the world's most populated economies such as Brazil, India and China also contributed enormously to the growth of international tourism. The emergence of these affluent middle classes and other factors discussed above meant massive movement of people and consequently an increase in tourist expenditure and an increase in both international, regional and national tourism (Sotiris \& Theodore, 2020). This increase in international tourist arrivals during that era brought about positive impacts to the hotel businesses as it boosted room occupancies and ultimately led to more revenue for the hospitality operations (Gössling et al., 2020).

\section{Tourism in Zimbabwe: An Overview}

The tourism industry in Zimbabwe has been on the recovery path since the land reform program which negatively impacted on international tourists' arrivals in the year 2000 (ZTA, 
2012). The look east policy adopted by the Government in 2003 saw the eastern region becoming one of the major sources of international tourists in Zimbabwe (Zibanai, 2018). The country's tourism industry has relied more on international tourism (ZTA, 2018) and table 1 shows international tourist arrivals to Zimbabwe from the major source regions.

Table 1. Tourist Arrival to Zimbabwe by Source Region (2018)

\begin{tabular}{|c|c|c|c|}
\hline Region & Tourist arrivals $(2017)$ & Tourist arrivals (2018) & Change \\
\hline Africa & $1,948,509$ & $2,064,534$ & $6 \%$ \\
\hline USA & 121,043 & 120,313 & $-1 \%$ \\
\hline Asia & 91,435 & 112,694 & $23 \%$ \\
\hline Europe & 218,140 & 232,233 & $6 \%$ \\
\hline Middle East & 7,537 & 7,798 & $3 \%$ \\
\hline Oceania & 36,266 & 42,402 & $17 \%$ \\
\hline Total & $2,422,930$ & $2,579,974$ & $6 \%$ \\
\hline
\end{tabular}

Source: ZTA Report, 2018

According to the Zimbabwe Tourism Authority (ZTA), the sector witnessed growth rate of $6 \%$ in 2018 as compared to 2017 largely due to growth in arrivals from its major source markets which are Africa, Europe, and Asia. This growth translated to an increase in tourism receipts from $\$ 918$ million in 2017 to $\$ 1.051$ billion in 2018 , which is a growth of $15 \%$, as a result of the increase in international tourist arrivals (ZTA, 2018). The World Travel and Tourism Council (WTTC) reported that tourism in Zimbabwe contributed 6\% to total economy in 2019 ((WTTC, 2020) This tourism growth due to an increase in international tourist arrivals contributed enormously to an increase in hotel occupancies. All regions in Zimbabwe (Table 2) experienced an increase in hotel occupancy with Victoria falls being a major attraction to international tourists recording an increase of $3 \%$ in average occupancy rate in that particular year (ZTA reprot, 2018).

Table 2. Average Hotel Occupancy Rates (2018)

\begin{tabular}{|l|c|c|}
\hline & Room Capacity & Room Occupancy \\
\hline Harare & 2317 & $63 \%$ \\
\hline Bulawayo & 785 & $51 \%$ \\
\hline Mutare/Vumba & 537 & $48 \%$ \\
\hline Nyanga & 244 & $45 \%$ \\
\hline Victoria Falls & 1128 & $58 \%$ \\
\hline
\end{tabular}

Source: ZTA report (2018)

Although the country witnessed a drop by $11 \%$ in tourist arrivals by end of 2019 due to destination image issues, there was still hope for a positive growth due to stakeholder 
intervention. While stakeholders were planning strategies to lure increased arrivals, Covid-19 posed a threat that has potential to topple the tourism sector particularly hotel businesses.

\section{Effects of the Pandemic on Hotel Operations}

This alarming increase in positive Covid 19 cases overwhelmed the health facilities in most countries. Unavailability of a Covid 19 prevention vaccine and no medical treatment for the disease (Wang \& Wang, 2020; Strielkowski, 2020b) prompted several governments to respond in several ways in an effort to contain the spread of the virus (Bakar \& Rosbi, 2020). Some of the ways in which governments responded include imposing lockdown of their economies (closing of boarders, only incoming residents and essential cargo allowed to cross boarders), grounding all airlines, home isolation, forced quarantine for incoming residents. Voluntary/mandatory quarantine, social distancing, closure of schools/universities, closure of all non-essential businesses, cancellation or postponing of all major events that involve international travel (Niestadt, 2020) and all events that require gathering of many people were banned (i.e. conferences, festivals, concerts, tradeshows, political debate, elections, sports seasons and worship gatherings) (Gössling et al., 2020).

All these mitigation measures restrict international, regional and national travel as countries closed their boarders and grounded their airlines. This brought nearly all areas in the tourism sector to a standstill (Hoque et al., 2020). Ironically, travel and tourism has been blamed for the spread of the virus across the globe causing major disruptions in tourism operations such as hotels and airlines worldwide (Niestadt, 2020; Ranasinghe et al., 2020). The lockdown regulations imposed by several countries are not favourable to tourism growth since tourism relies on travel of people within and across borders. International tourism has been hard hit by the virus and Sotiris \& Theodore (2020) labelled tourism as "the great patient of the Covid 19 pandemic". Airlines and hotel businesses are the most affected since their business relies mainly on international, regional and national travel.

Although Niestadt (2020) noted that it is too early to estimate the full impact of this pandemic on the global economy, UNWTO is estimating a huge fall of between US $\$ 300-\$ 450$ 
billion in international tourism receipt as a result of this pandemic. This represents about one third of what was generated in 2019. UNWTO estimate this to be equivalent to a loss of between five to seven years' worth of tourism growth (PwC Advisory, 2020). A 40\% to 60\% fall in international tourist arrivals is expected in 2020 as compared to arrivals in 2019 because of the travel restrictions imposed by countries and the cancellation or postponement of major events (Niestadt, 2020; Santos del Valle, 2020; PwC Advisory, 2020). The hospitality industry has been paralysed by this pandemic and UNWTO estimates a decline of $20 \%$ of its turnover since a fall in tourist arrivals will directly affect hotel occupancies and ultimately revenues (AU, 2020; Napierała et al., 2020). Oxford Economics (2020) conducted a thorough economic impact of COVID-19 on hotel occupancy in the US and estimated a decline of $20 \%$ in hotel occupancy, which translate to 380 million loss in hotel room nights.

A decline in tourist arrivals translate to a decline in the demand for hotel services and thus many hotels worldwide have closed down as a result. In France hotel occupancy rate dropped from $65.3 \%$ on 26 February to $3.3 \%$ on 17 March. In mainland China a lockdown was imposed on 23 January, the hotel market dropped by $89 \%$ and operated at an occupancy rate below 10\% for 22 consecutive days (PwC Advisory, 2020). By 30 March hotels, restaurants and bars in most European countries had closed down laying off thousands of workers. Some hotels were turned into quarantine centres providing free accommodation to sick employees to avoid spreading the disease to their families while others hotels were turned into temporary hospitals (Niestadt, 2020). As the virus continued to spread worldwide, the impact has continued to spread to other hospitality markets and the full impact of this pandemic is now being felt by every business in the hospitality sector across the globe including in Zimbabwe.

The effects of Covid 19 pandemic fuelled up by travel restrictions imposed worldwide in a bid to stop the spread of the virus did not spare the already suffering tourism and hospitality industry in Zimbabwe (ZCTU, 2020). Currently the tourism industry in Zimbabwe is at a halt, just like anywhere else in the world. The country's first case of COVID-19 was reported on 20 March with two imported cases (Ministry Of Health and Child Care, 2020). The number of cases then increased steadily with most of the cases being imported. Local transmissions 
began to be witnessed in the country's cities of Harare and Bulawayo and the government quickly responded by imposing a national lockdown on 30 March 2020. Tourism towns such as Victoria Falls started 'feeling the heat' soon after government announced lockdown measures including closure of borders, travel bans and self-isolation (ZCTU, 2020).

By end of September, the country had recorded at 7683 positive cases, 5924 recoveries and 225 deaths (Ministry Of Health and Child Care Situation Report, 24 September 2020). Although the numbers of positive cases in Zimbabwe appeared very low as compared to the rest of the world, the impact of this pandemic to Zimbabwe's tourism industry in general and hotel sector in particular, is as hard and tremendous as anywhere else in the world. This is mainly because the country's tourism sector largely depend on international tourism with Europe, Asia and the United States of America being the major source markets (ZTA Report, 2018). It is therefore fundamental for hospitality researchers to determine full impact of the pandemic on hotel sectors in their respective countries and provide recommendations for quick recovery. While the media has reported on the general impacts of the pandemic on the hospitality industry, no scientific enquiry has been made to establish the real impact on the performance of hotels in Zimbabwe. This paper therefore sought to close that gap.

\section{Strategies That Hotel Businesses Can Adopt}

COVID-19 has impacted severely on international travel and on demand for hospitality services especially accommodation. Other industries such as the energy industry have been impacted in the same manner, but the difference is that all other industries are necessities whereas the travel and hospitality industry is regarded as non-essential thus it is very sensitive to shocks such as the COVID-19 pandemic (Bakar \& Rosbi, 2020). Hotels are therefore more susceptible to the effects of reduced travel caused by government-ordered lockdown (Jiang \& Wen, 2020). Hotel businesses are in a fight for survival as cancellation and postponement of major events inflict severe blows on hoteliers globally (Santos del Valle, 2020).

It is therefore of paramount importance to explore strategies that the hospitality industry can adopt in order to sustainably survive in the dramatic changes brought by the pandemic 
(Chang et al., 2020). Jamal and Budke (2020) highlighted that extensive research on recovery strategies is required especially for vulnerable destinations in developing regions. Hoteliers need to assess and adopt the ones that suit their environments. Some of these strategies can be borrowed from past catastrophes such as the September 9/11 attacks and the SARS (Severe Acute Respiratory Syndrome) outbreak in 2002-2003 (Santos del Valle, 2020; Jiang \& Wen, 2020). Table 3 shows recovery strategies from the SARS outbreak. This study aims to explore strategies that hoteliers in Zimbabwe can take up in order to tackle these huge blows posed upon them by COVID-19.

Table 3. Recovery Strategies from the SARS Outbreak

\begin{tabular}{|l|l|}
\hline \multicolumn{1}{|c|}{ Author } & \multicolumn{1}{c|}{ Recovery strategy } \\
\hline Mao et al (2010) & $\begin{array}{l}\text { Use of mass media campaigns to improve visitor confidence regarding } \\
\text { the destination in terms of its safety. } \\
\text { Use of individualized marketing channels to reduce perceived risk of } \\
\text { individual travellers }\end{array}$ \\
\hline Tew et al (2008) & $\begin{array}{l}\text { Global collaboration and cooperation between governments and health } \\
\text { organisations to ensure transparency in dealing with the crisis. } \\
\text { Promoting domestic tourism. }\end{array}$ \\
\hline Leung \& Lam (2008) & $\begin{array}{l}\text { Hotels to follow international standards of hygiene and health. } \\
\text { Provide specific training for employees about hygiene. } \\
\text { Establish internal standards and operational procedures. }\end{array}$ \\
\hline Kim et al (2005) & $\begin{array}{l}\text { Offering discounted restaurant and room prices. } \\
\text { Establishing a crisis management framework. }\end{array}$ \\
\hline Hung et al (2018) & $\begin{array}{l}\text { Travel screening. } \\
\text { Timely reporting and isolation of infected guests }\end{array}$ \\
\hline
\end{tabular}

\section{METHOD}

The study was exploratory and made use of online administered questionnaires to collect data. The target population constituted of all registered hotels in Zimbabwe, according to ZTA 2021 statistics of registered operators there are 72 registered hotels. Since the target population is highly homogenous a sample size of 30 hotels around Zimbabwe, the hotel General Managers (or their representatives) being the targeted respondents. The sample size determined using the degree of variability for determining sample size. The theory states that the more homogenous a population is the smaller the sample size. According to Kish (1995) when similar attributes are present 20 to $80 \%$ of the time a sample size 30 is sufficient. An online questionnaire was administered to hotels in Zimbabwe. The online survey was relatively cheap; it eliminated paperwork and reached the target respondents, who would otherwise not 
have been reached due to travel restrictions in the country. The respondents were conveniently selected from the Zimbabwe Tourism Authority's hotels database targeting 3 to 5-star hotels, assuming they are the hardest hit by COVID-19 pandemic. The Statistical Package for Social Scientist (SPSS) version 23 was used to analyse the data.

\section{RESULTS AND DISCUSSION}

The findings of the study are presented and discussed in this section. Analysing firstly the hotel business performance due to COVID-19 outbreak, secondly the hotel revenue, thirdly the strategies being taken by hotels since the outbreak of the COVID-19 pandemic and lastly recovery strategies mitigating the impact of COVID-19 aftermath.

\section{Hotel Business Performance due to COVID-19 Outbreak}

Most of the Hotel Managers (93.1\%) agreed that business drastically declined to unprecedented levels in a very short space of time. Close to $90 \%$ percent cited a decline in the number of functions, hotel occupancy and restaurant business declined due to the COVID19 pandemic $(89.7 \%)$.

Table 4. Frequency of Respondents

\begin{tabular}{|l|c|c|}
\hline $\begin{array}{c}\text { Observed Variable \{in agreement with hotel business performance } \\
\text { due to COVID-19 outbreak\} }\end{array}$ & Number & Percentage \\
\hline Hotel occupancies and revenue decreased & 27 & 93.1 \\
\hline Decline in number of functions at hotel due to COVID-19 pandemic & 26 & 89.7 \\
\hline Restaurant Business declined due to COVID-19 pandemic & 26 & 89.7 \\
\hline $\begin{array}{c}\text { Observed Variable \{in disagreement with hotel business performance } \\
\text { due to COVID-19 outbreak\} }\end{array}$ & Number & Percentage \\
\hline Hotel occupancies and revenue unaffected & 22 & 75.9 \\
\hline Hotel occupancies and revenue increased & 28 & 96.6 \\
\hline
\end{tabular}

The results revealed that the hotel occupancies dropped to less than $4 \%$ as shown in table 4 with respondents in disagreement with hotel occupancies and revenue increased with 96.6\%. The same findings were revealed by Hoque, et al., (2020) in China and by Niaperala, et al., (2020) in China and Polish cities where hotel occupancy dropped to $10 \%$ and $3 \%$ respectively at the peak of COVID-19 pandemic. 


\section{Hotel Business Revenue Decrease Due to COVID-19 Pandemic}

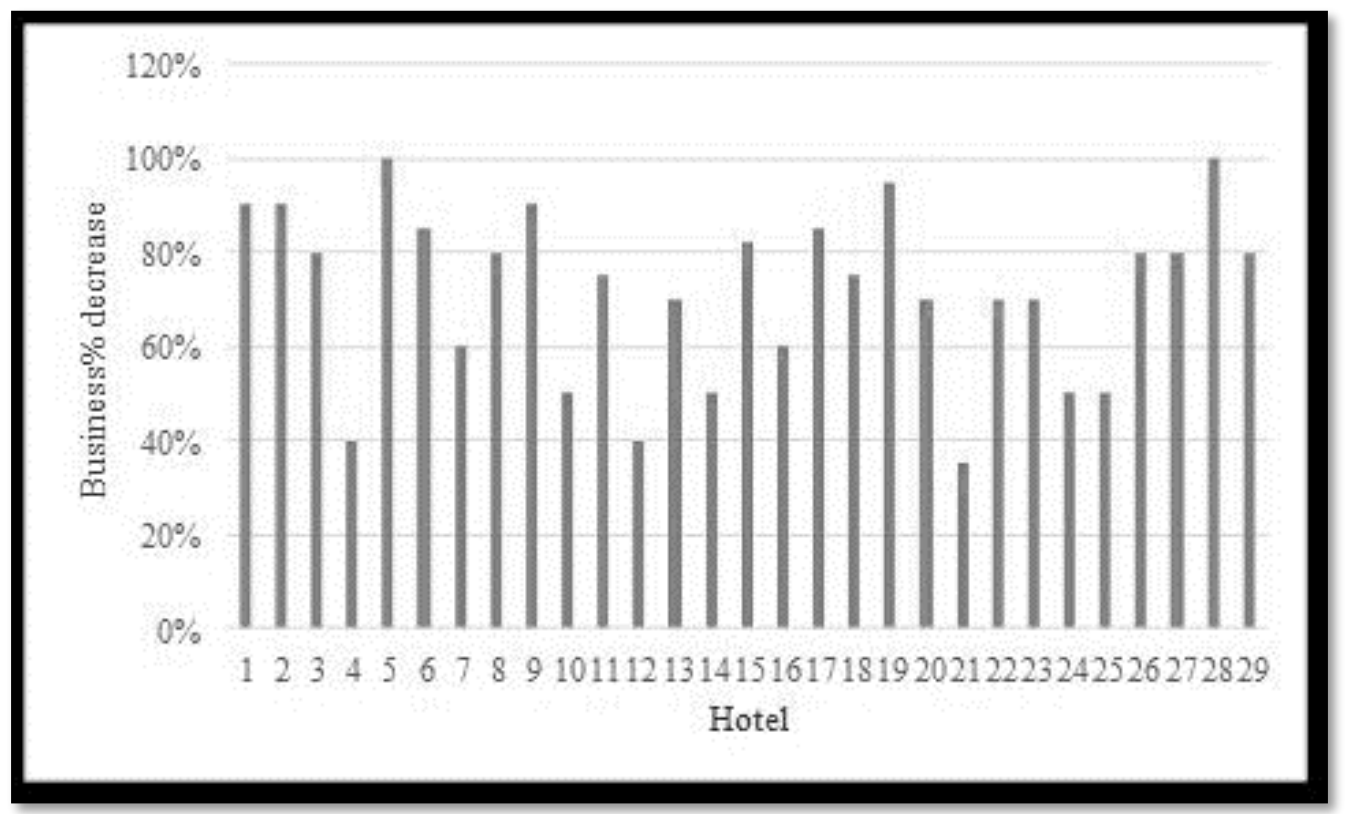

Figure 2. Hotel Business Revenue Decrease

The results revealed a massive hotel revenue decrease in the second quarter of 2020 as compared to second quarter of 2019. The respondents did not respond to how much they have lost due to COVID-19 outbreak in terms exact monetary value but indicated probable percentages. The hotels lost above $75 \%$ of their revenue as shown in figure 2 . Two hotels were totally affected by the COVID-19 outbreak as the revenue dropped by $100 \%$ since the hotels completely stopped operations.

\section{Strategies being taken by hotels since the outbreak of COVID-19 pandemic}

Table 5 to table 7 below shows the frequency analysis of respondents on the strategies being taken to manage the situation.

Table 5. Frequency of Respondents

\begin{tabular}{|l|c|c|}
\hline \multicolumn{1}{|c|}{$\begin{array}{c}\text { Observed Variable } \begin{array}{c}\text { in agreement with strategies being taken by } \\
\text { hotels since the outbreak of COVID-19\} }\end{array} \\
\text { Closed hotel floors }\end{array}$} & Pumbercentage \\
\hline Cut salaries. & 24 & 82.8 \\
\hline Increased sanitation & 20 & 69 \\
\hline Provide masks and gloves & 28 & 96.6 \\
\hline Check employee temperature & 28 & 96.6 \\
\hline Check guest temperature & 28 & 96.6 \\
\hline Change physical layout & 25 & $96.6 \%$ \\
\hline Phone orders & 18 & 66.2 \\
\hline
\end{tabular}




\begin{tabular}{|l|c|c|}
\hline $\begin{array}{c}\text { Observed Variable \{in disagreement with strategies being taken by } \\
\text { hotels since the outbreak of COVID-19\} }\end{array}$ & Number & Percentage \\
\hline Retrenched staff & 17 & 58.6 \\
\hline Door delivery & 15 & 51.7 \\
\hline Opening up the hotel as a quarantine centre & 25 & 86.2 \\
\hline
\end{tabular}

The majority of responses were in agreement on closure of some hotel floors (82.8\%), cut salaries (69\%), increased sanitation (96.6\%), provide masks and gloves (96.6\%), check employee temperature (96.6\%), check guest temperature (96.6\%), change physical layout $(86.2 \%)$ and phone orders (62.1\%). Respondents were in disagreement with three out of twelve statements on strategies namely, retrench staff (58.6\%), door to door food delivery (51.7\%) and opening up the hotel as a quarantine centre (86.2\%). It is interesting to note that the strategies being taken by hotels since the outbreak of COVID-19 pandemic are in line with the World Health Organisation (WHO) and Ministry of Health and Child Care COVID-19 health guidelines which included increased sanitation, provide masks and gloves, check guest temperature, check employee temperature and change physical layout.

Table 6. Frequency Distribution Table on Online Orders Strategy

\begin{tabular}{|c|c|c|c|c|c|}
\hline & Frequency & Percent & Valid Percent & Cumulative Percent \\
\hline \multirow[t]{6}{*}{ Valid } & strongly disagree & 2 & 6.9 & 6.9 & 6.9 \\
\hline & Disagree & 8 & 27.6 & 27.6 & 34.5 \\
\hline & Neutral & 6 & 20.7 & 20.7 & 55.2 \\
\hline & Agree & 5 & 17.2 & 17.2 & 72.4 \\
\hline & strongly agree & 8 & 27.6 & 27.6 & 100.0 \\
\hline & Total & 29 & 100.0 & 100.0 & \\
\hline
\end{tabular}

On the strategies adopted it is important to note that on online delivery only $44.8 \%$ were in agreement, $34.5 \%$ in disagreement and $20.7 \%$ being neutral (table 6 ). The finding reveals that adoption of the online strategy is still under consideration, hotel players have some reservations and moreover, it shows that in general Zimbabwe hotel tourism needs further education on payoffs of adopting online business strategies especially in the modern age and in such times as COVID-19 pandemic. 
Table 7. Frequency Distribution Table On Door-To-Door Food Delivery Strategy

\begin{tabular}{|c|c|c|c|c|c|}
\hline & & Frequency & Percent & Valid Percent & $\begin{array}{c}\text { Cumulative } \\
\text { Percent }\end{array}$ \\
\hline \multirow[t]{6}{*}{ Valid } & strongly disagree & 8 & 27.6 & 27.6 & 27.6 \\
\hline & Disagree & 7 & 24.1 & 24.1 & 51.7 \\
\hline & Neutral & 9 & 31.0 & 31.0 & 82.8 \\
\hline & Agree & 1 & 3.4 & 3.4 & 86.2 \\
\hline & strongly agree & 4 & 13.8 & 13.8 & 100.0 \\
\hline & Total & 29 & 100.0 & 100.0 & \\
\hline
\end{tabular}

The door-to-door deliveries results reveal that only $51.7 \%$ are in disagreement with it being adopted whilst the other half is either in disagreement and neutral (Table 7). It can be concluded that hotel operators in Zimbabwe are yet to embrace door-to-door food deliveries, like the online orders. There is therefore need for more innovation in times of such crisis as the COVID-19 pandemic.

The results revealed that nearly all hotels considered closing their facilities and to continued operating on takeout and continued operation only for essential staff, offering vulnerable population accommodation. This means that with this level of operation business drastically dropped. The results also revealed that none of the hotel in this study was turned into a quarantine centre or COVID-19 patients' hospital in Zimbabwe. This means that they were not getting any revenue from their rooms division, which normally sustains most hotels. In other countries some hotels were turned into health facilities like in Brazil, Spain and India (Xinhua News, 2020 (CNN, 2020). In neighbouring Botswana, many hotels, especially those in Gaborone and near ports of entry, were used as quarantine centers. 


\section{Recovery Strategies Mitigating the Impact of COVID-19 Aftermath}

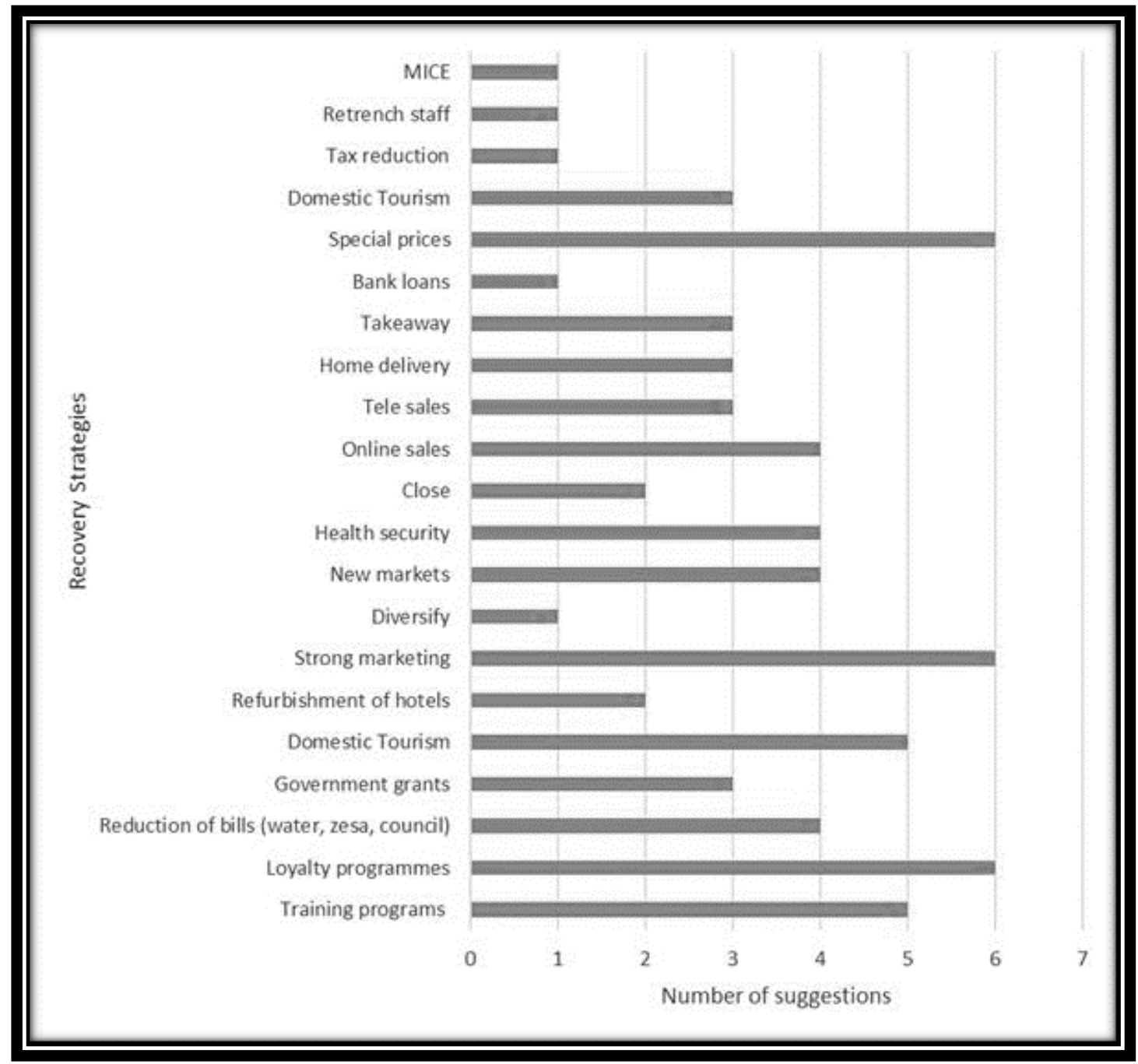

Figure 3: Shows the Recovery Strategies Mitigating the Impact of COVID-19 Aftermath

Six out of the 29 respondents proposed the introduction of loyalty programmes, strong tourism marketing and special prices. Second most suggested strategies are training programs, promoting domestic tourism, and reduction of operating bills, looking for new markets and strict adherence to WHO Covid-19 guidelines. Three respondents suggested government grants, concentrating on domestic tourism, home food deliveries, take away telesales while two respondents resorted to refurbishment and a difficult one of closing hotel. The least suggested strategies given by just one respondent each are retrench staff, tax reduction, taking bank loans, venturing into the MICE market, and diversifying from hotel business. 
The above findings are in line with Mao et al (2010), Leung \& Lam (2008) and Hung et al (2018) recovery strategies from SARS outbreak. The results indicated that the hotels heavily banked on the government as key enabler for their quick recovery from COVID-19 pandemic as need for government grants, reduction of bills, tax reduction, health security and domestic tourism which are hinged on government.

\section{CONCLUSION}

It can be concluded that the hotel sector in Zimbabwe was hard hit by the Covid-19 pandemic and is not close to being prepared to deal with pandemics like the Covid- 19 . Occupancies went down to record low and revenue reduced by an average of $75 \%$. This has seen to many hotels adopting various strategies to try and stay afloat during such a period of economic turmoil. Since the pandemic has affected hotels in Zimbabwe in the same manner it has affected the hotel industry globally, there is need to benchmark on what other players are doing to survive. This study therefore provides an insight into the Zimbabwean situation, being to light how Zimbabwean 3-5-star hotels have been affected by the global pandemic. In future the hotels can prepare to manage pandemics of this nature. The study was carried out among registered hotels of 3-to-5-star rating only which might jeopardise the inferencing of the results to the whole industry since the hotels are of different ratings.

Based on the findings, this paper recommends that hotels should develop and implement disaster management plans that are specific to pandemics like the Covid-19. Hotels should consider investing in insurance schemes that cover them in times like these. While such investments may seem expensive, they will come in handy in times of crisis. This is especially important in countries like Zimbabwe where the government cannot bail out companies in distress. As the travel restrictions are being gradually relaxed, the Zimbabwe Tourism Authority in collaboration with the Hospitality Association of Zimbabwe need to come up with deliberate strategies to promote domestic tourism. The hotel sector must refrain from profiteering and come up with a pricing regime which accommodates local tourists. Future 
research can focus on developing frameworks for the hospitality sector for coping during pandemics.

\section{REFERENCES}

AU. (2020). Impact of the Coronavirus (Covid 19) on the Africa Economy.

Bakar, N. A., \& Rosbi, S. (2020). Effect of Coronavirus disease (COVID-19) to tourism industry. International Journal of Advanced Engineering Research and Science, 7(4), 189-193.

Chang, C., Mcaleer, M., \& Ramos, V. (2020). A Charter for Sustainable Tourism after COVID19. Sustainabilty, 10-13.

Folinas, S ., \& Metaxas, T . (2020) . Tourism . The Great Patient of Coronavirus, COVID-2019 . Advance online publication . https://doi .org/10 .13140/RG .2 .2.12069.24804

Gössling, S., Scott, D., Hall, C. M., Gössling, S., Scott, D., \& Pandemics, C. M. H. (2020). Pandemics, tourism and global change: a rapid assessment of COVID-19. Journal of Sustainable Tourism, O(0), 1-20. https://doi.org/10.1080/09669582.2020.1758708

Hoque, A., Shikha, F. A., Hasanat, M. W., \& Arif, I. (2020). The Effect of Coronavirus ( COVID19 ) in the Tourism Industry in China. Asian Journal of Multidisciplinary Studies, 3(1).

Hung, K. K. C., Mark, C. K. M., Yeung, M. P. S., Chan, E. Y. Y., \& Graham, C. A. (2018). The role of the hotel industry in the response to emerging epidemics: A case study of SARS in 2003 and H1N1 swine flu in 2009 in Hong Kong. Globalization and Health, 14(1), 1-7. https://doi.org/10.1186/s12992-018-0438-6

International Labour Organization. (2020). International Labour Organisation Sectoral Brief.

Jamal, T., \& Budke, C. (2020). Tourism in a world with pandemics: local-global responsibility and action. Journal of Tourism Features. https://doi.org/10.1108/JTF-02-2020-0014

Jiang, Y., \& Wen, J. (2020). Effects of COVID-19 on hotel marketing and management: A perspective article. International Journal of Contemporary Hospitality Management, 32 (8), 2563-2573.

Kim, S. S., Chun, H., \& Lee, H. (2005). The effects of SARS on the Korean hotel industry and measures to overcome the crisis: A case study of six Korean five-star hotels. Asia Pacific Journal of Tourism Research, 10(4), 369-377. https://doi.org/10.1080/10941660500363694

Kish, L.(1995). Survey Sampling. New York:John Wiley and Sons, Inc

Leung, P., \& Lam, T. (2008). Crisis Management during the SARS Threat. Journal of Human Resources in Hospitality \& Tourism, 3(1), 19-32. https://doi.org/10.1300/J171v03n01

Mao, C. K., Ding, C. G., \& Lee, H. Y. (2010). Post-SARS tourist arrival recovery patterns: An analysis based on a catastrophe theory. Tourism Management, 31(6), 855-861. https://doi.org/10.1016/j.tourman.2009.09.003

Ministry Of Health and Child Care. (n.d.). Covid-19 Update.

Napierała, T., Napierala-Lesniewska, K., \& Burski, R. (2020). Impact of Geographic Distribution of COVID-19 Cases on Hotels 'Performances: Case of Polish Cities. Sustainability, 1-18.

Niestadt, M. (2020). COVID-19 and the tourism sector. Retrieved from http://www.europarl.europa.eu/thinktank

Oxford Economics. (2020). Economic Impact Of The Hotel Industry Showcases: Potential Negative Impact of Coronavirus Pandemic (p. 500). p. 500.

Ozili, P. K., \& Arun, T., Spillover of COVID-19: Impact on the global economy, Social Science Research Network 2020. https://doi.org/10.2139/ssrn.3562570

PwC Advisory. (2020). Hotels - response to Covid-19.

Ranasinghe, R., Damunupola, A., Wijesundara, S., Karunarathna, C., Nawarathna, D., Gamage, S., ... \& Idroos, A. A. (2020). Tourism after Corona: Impacts of Covid 19 Pandemic and Way Forward for Tourism, Hotel and Mice Industry in Sri Lanka. Hotel and 
Mice Industry in Sri Lanka (April 22, 2020).

Santos del Valle, A. (2020). The Tourism Industry and the Impact of Covid-19 Scenarios and Proposals.

Sotiris, F., \& Theodore, M. (2020). 'Tourism : The Great Patient of Coronavirus COVID-2019'” (No. 99666). Retrieved from https://mpra.ub.uni-muenchen.de/99666/

Strielkowski, W. (2020). International Tourism and COVID-19: Recovery Strategies for Tourism Organisations. (March). https://doi.org/10.20944/preprints202003.0445.v1

Tew, P. J., Lu, Z., Tolomiczenko, G., \& Gellatly, J. (2008). SARS: Lessons in strategic planning for hoteliers and destination marketers. International Journal of Contemporary Hospitality Management, 20(3), 332-346. https://doi.org/10.1108/09596110810866145

Wang, J., \& Wang, Z. (2020). Strengths, Weaknesses, Opportunities and Threats ( SWOT ) Analysis of China's Prevention and Control Strategy for the COVID-19 Epidemic. International Journal of Environmental Research and Public Health, 2019.

WTTC. (2020). Zimbabwe 2020 Annual Research: Key highlights.

ZCTU. (2020). Zctu response to the impact of covid-19 (coronavirus) pandemic on workers and the zimbabwean economy, march 31, 2020 (Vol. 19). Retrieved from https://www.ituc-csi.org

Zibanai, Z. (2018). The Tourism Sector : A bright light in Zimbabwe`s depressed economic environment. African Journal of Hospitality, Tourism and Leisure, 7(1), 1-15.

ZTA. (2012). Tourism \& Trends Statistics Report 2012. Zimbabwe Tourism authority, Harare

ZTA. (2018). Tourism Trends \& Statistics Report. Zimbabwe Tourism authority, Harare 